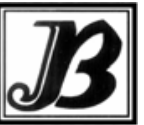

J. bio-sci. 19: 81-87, 2011

ISSN 1023-8654

http://www.banglajol.info/index.php/JBS/index

\title{
GENETIC DIVERSITY IN WILD AND HATCHERY POPULATIONS OF STINGING CATFISH (HETEROPNEUSTES FOSSILIS BLOCH) REVEALED BY RAPD ANALYSIS
}

\author{
Md Nazrul Islam, Abhishak Basak, Ashrafullah, Md Samsul Alam* \\ Department of Fisheries Biology and Genetics, Bangladesh Agricultural University, Mymenmsingh
}

\begin{abstract}
Context: DNA fingerprinting using genetic markers such as Random Amplification of Polymorphic DNA (RAPD), Restriction Fragment Length Polymorphism (RFLP), microsatellite (Simple sequence repeat), Amplified Fragment Length Polymorphism (AFLP) etc. can be successfully used to reveal genetic variation within and among different populations.
\end{abstract}

Objective: The aim of the present study was to assess genetic diversity in two wild and one hatchery populations of stinging catfish Heteropneustes fossilis by RAPD fingerprinting.

Materials and Methods: A total of 90 live fish ( $H$. fossilis), 30 from each source, were collected from a beel in Patuakhali, a beel in Jessore and Rupali Hatchery, Mymensingh. Genomic DNA was extracted from fin tissues. The concentration of DNA was estimated using a spectrophotometer. Fifteen decamer primers of random sequence from three kits (six from kit A, seven from kit B and two from kit C) (Operon technologies, Inc., Alameda, CA, USA) were screened on sub-samples of one randomly chosen $H$. fossilis DNA sample from the each population to test their suitability for amplifying RAPDs. The amplified products from each sample were separated by electrophoresis on $1.4 \%$ agarose gel containing ethidium bromide. The sizes of the bands were calculated using the software DNAFRAG and the sizes in base pair (bp) were used for identification of the bands (RAPD markers). The similarity index values (SI) between the RAPD fingerprint of any two individuals on the same gel were calculated from RAPD band sharing.

Results: A total of 28 RAPD bands were obtained using four decamer random primers, among which 21 bands were polymorphic. The percentage of polymorphic loci, intra-population similarity indices and Nei's gene diversity values were $85.71 \%, 78.75$ and $0.304 \pm 0.183$ for Jessore population, $83.71 \%, 82.62$ and $0.280 \pm 0.159$ for Patuakhali population, $82.14 \%, 85.25$ and $0.271 \pm 0.165$ for Rupali hatchery population, respectively. The overall gene flow $\left(\mathrm{N}_{\mathrm{m})}\right.$ among the populations was 5.755 . The highest inter-similarity $\left(\mathrm{S}_{\mathrm{i}}\right)$ was found between Patuakhali - Rupali hatchery populations. Among the three populations, the highest genetic distance $(0.069)$ was found between Jessore and Patuakhali population. Considering polymorphic loci, intrapopulation similarity index and gene diversity the genetic variation in the Jessore population was higher than the other two populations. The genetic variation of the hatchery population was found to be lower than the two wild populations.

Conclusion: The result of the present study can be used as baseline information regarding the genetic variation and population structure before undertaking any breeding programme. Study indicated that the genetic variation in the hatchery populations were slightly lower than those of the wild populations.

Keywords: catfish, DNA fingerprinting, gene diversity, polymorphism

\section{Introduction}

Stinging catfish, Heteropneustes fossilis (Bloch) belongs to the family Heteropneustidae of the order Siluriformes. Members of Heteropneustidae family are collectively known as 'airsac catfishes' for carrying airsacs as accessory respiratory organ. The catfishes together form a group of commercially important and popular fish species in Bangladesh. The total annual production of catfish was 117,856 mt in 2008-2009 which was $4.36 \%$ of the total inland fish production of the country (DoF 2010). H. fossilis is native to Bangladesh, Pakistan, India, Nepal, Srilanka, Burma, Thailand and Laos (Talwar and Jhingran 1991). It occurs in all types of inland water bodies and survives for a long time when kept in captivity even in a small quantity of water as it has massive paired sac-like pharyngeal lungs as accessory respiratory organs (Das 1972). The species is popular for its good taste and ability to survive in poorly oxygenated waters.

*Corresponding author Email: samsul_bau@yahoo.com 
Habitat degradation caused by natural and human interventions and injudicious application of pesticides in agricultural fields are considered to be great threats for fish biodiversity in Bangladesh. The availability of fishes in the natural waterbodies has been substantially reduced in the last two decades. The reduction in population size may result in decrease in genetic variation through bottleneck effects, genetic drift and inbreeding. Genetic variation refers to the differences in the hereditary constitutions of the individuals of a species which is important in maintaining the developmental stability and biological potential of a stock. Therefore, information on genetic variability of any stock obtained by using appropriate molecular markers would be helpful to assess any genetic deterioration that might have taken place as well as to develop management plans for conservation and stock improvement.

DNA fingerprinting using genetic markers such as Random Amplification of Polymorphic DNA (RAPD), Restriction Fragment Length Polymorphism (RFLP), microsatellite (Simple sequence repeat), Amplified Fragment Length Polymorphism (AFLP) etc. can be successfully used to reveal genetic variation within and among different populations. Among the DNA markers, RAPD fingerprinting technique is simple, fast, sensitive and allows the examination of genomic variation without prior knowledge of DNA sequences (Williams et al. 1990, Welsh and McClelland 1990, Hadrys et al. 1992). RAPD markers are generated by PCR amplification from genomic DNA with short single primer of arbitrary nucleotide. RAPD markers have a wide range of applications in gene mapping, population genetics, molecular evolutionary genetics and plant and animal breeding (Bardakci and Skibinski 1994). The aim of the present study was to assess genetic diversity in two wild and one hatchery populations of stinging catfish $\mathrm{H}$. fossilis by RAPD fingerprinting. .

\section{Materials and Methods}

Collection of fish samples: A total of 90 live fish ( $H$. fossilis), 30 from each source, were collected from a beel in Patuakhali, a beel in Jessore and Rupali Hatchery, Mymensingh during April-May, 2011. Fin samples were clipped from caudal fin of each fish and immediately preserved in separate microfuge tubes containing $95 \%$ ethanol and kept in freezer $\left(-20^{\circ} \mathrm{C}\right)$ until used for DNA extraction.

Isolation of genomic DNA: Genomic DNA was extracted from fin tissues according to the method described by Islam and Alam (2004). Briefly, approximately $40 \mathrm{mg}$ of fin tissues were cut into small and ground in extraction buffer $(100 \mathrm{mM}$ Tris. $\mathrm{HCl}, 250 \mathrm{mM} \mathrm{NaCl}, 10 \mathrm{mM}$ EDTA and 1\% SDS) and incubated with proteinase-K overnight at $37^{\circ} \mathrm{C}$. DNA was purified by two extractions- one with equal volume phenol: chloroform: isoamylalcohol $(25: 24: 1 ; \mathrm{v} / \mathrm{v} / \mathrm{v})$ and one with chloroform: isoamylalcohol (24:1; v/v) and precipitated using isopropanol and ethanol. The concentration of DNA was estimated using a spectrophotometer (Biophotometer Plus, Eppendorf, Germany).

Polymerase chain reaction (PCR): Fifteen decamer primers of random sequence from three kits (six from kit A, seven from kit B and two from kit C) (Operon technologies, Inc., Alameda, CA, USA) were screened on sub-samples of one randomly chosen $H$. fossilis DNA sample from the each population to test their suitability for amplifying RAPDs. Finally, four primers exhibiting highest quality banding patterns and sufficient variability were used for analysis of all the samples. PCR reactions were performed in $10 \mu \mathrm{l}$ reaction mix containing $1 \mu \mathrm{l}$ of $10 \mathrm{x}$ Taq polymerase buffer, $2 \mu \mathrm{M}$ of each primer, $0.25 \mathrm{mM} \mathrm{dNTPs}$ and 1 unit of Taq DNA polymerase (GENEI, Bangalore, India) and 150ng $\mu$ lof genomic DNA. The reaction mix was preheated at $94^{\circ} \mathrm{C}$ for 3 min followed by 40 cycles of 1 min denaturation at $94^{\circ} \mathrm{C}, 1$ min annealing of PCR primers at $36^{\circ} \mathrm{C}$ and 2 min elongation at $72^{\circ} \mathrm{C}$. After the last cycle, a final step of $7 \mathrm{~min}$ at $72^{\circ} \mathrm{C}$ was added to allow complete extension of all amplified fragments.

Electrophoresis of amplified products and analysis of RAPD data: The amplified products from each sample were separated by electrophoresis on $1.4 \%$ agarose gel containing ethidium bromide. Electrophoresis was performed at $100 \mathrm{~V}$ for 45 mins. Lambda DNA/HindllI-EcoRl digest and 100bp DNA ladder were electrophoresed along side the RAPD reactions as molecular weight markers. DNA bands were observed using a digital Gel documentation system and image was saved on computer. 
RAPD patterns were visually analyzed and scored from the photographs of the gel. For the analysis and comparison of the patterns, only the well-separated clearly visible bands were scored. The sizes of the bands were calculated using the software DNAFRAG (Nash 1991) and the sizes in base pair (bp) were used for identification of the bands (RAPD markers). The RAPD markers were scored by recording the presence (1) or absence (0) of these bands for each fish and each primer. A single data matrix was constructed pooling the binary data $(1 / 0)$ for all the primers and used for estimating gene frequency, polymorphic loci, Nei's (1973) gene diversity, observed number of alleles $(\mathrm{Na})$, effective number of alleles $(\mathrm{Ne})$, gene flow $(\mathrm{Nm})$, and genetic distance with the POPGENE (Version 1.31) (Yeh et al. 1999) computer program.

The similarity index values (SI) between the RAPD fingerprint of any two individuals on the same gel were calculated from RAPD band sharing according to the following formula: Similarity index (SI) $=N_{A B} /\left(N_{A}+N_{B}\right)$, Where, $N_{A B}$ is the total number of RAPD bands shared by individuals $A$ and $B$, and $N_{A}$ and $N_{B}$ are the total number of bands produced by individual A and B, respectively (Lynch 1990). Within population similarity [S $\mathrm{S}]$ was calculated as the average of $\mathrm{SI}$ across all possible comparisons between individuals within a population. Between population similarity (Sij), was calculated as the average similarity between randomly paired individuals from populations $\mathrm{i}$ and $\mathrm{j}$ (Lynch 1991).

\section{Results}

RAPD profiles and polymorphism generated by PCR: Among the 15 primers initially tested, four primers: OPA01, OPB01, OPB02, and OPB19 yielded comparatively larger number of bands with good resolution. Each primer produced a unique fragment pattern of amplified DNA with varied numbers of bands. The four primers yielded a total of 28 reproducible and consistently storable RAPD bands of which 21 (75\%) were polymorphic $\left(\mathrm{P}_{95}\right)$. Primers OPB02 and OPB19 gave DNA profiles with more bands than OPA01 and OPB01. RAPD profile obtained for primer OPB01 and OPB02 are shown in Fig. 1. The sizes of the bands ranged from 250-1769 bp (Table 1).

Genetic variation in the populations: The proportion of polymorphic loci was highest in the Jessore population $(85.71 \%)$ while that in the Rupali hatchery population was the lowest (82.14) (Table 2). The intra-population similarity or within population similarity indices $(S i)$ for Rupali hatchery population were found to be higher followed by that of Patuakhali population. The Si value for Jessore population was found to be the lowest (Table 2). The gene diversity of the Jessore population was higher $(0.3036 \pm 0.1827)$ than the Patuakhali $(0.280 \pm 0.1585)$ and Rupali hatchery $(0.2714 \pm 0.1654)$ population. The observed number of allele in Jessore population was also highest and that of the hatchery population was the lowest. However, the effective number of alleles and Shannon's information index (I) in the hatchery population were higher than those of the Jessore and Patuakhali population. The overall gene flow $(\mathrm{Nm})$ among the populations was 5.755 (Table 2).

Genetic identity and genetic distances: The values for inter-population genetic identity were $0.9330,0.9356$ and 0.9764 for Jessore and Patuakhali, Jessore and Rupali hatchery, Rupali hatchery and Patuakhali respectively. The genetic distances were $0.0694,0.0666$ and 0.0238 for Jessore and Patuakhali, Jessore and Rupali hatchery, Rupali hatchery and Patuakhali, respectively (Table 3).

Table 1. Primers used to generate RAPD fingerprint with total and polymorphic bands obtained per primers from the $H$. fossilis DNA

\begin{tabular}{llcccc}
\hline Primer code & Sequence $\left(5^{\prime}-3^{\prime}\right)$ & Total No. of bands & Size range $(\mathrm{bp})$ & Polymorphic band & Polymorphism \% \\
\hline OPA01 & CAGGCCCTTC & 6 & $350-1636$ & 5 & 83.33 \\
OPB01 & GTTTCGCTCC & 6 & $250-1625$ & 4 & 66.66 \\
OPB 02 & TGATCCCTGG & 8 & $250-1769$ & 6 & 75.00 \\
OPB19 & TTCCCCCGCT & 8 & $300-1647$ & 6 & 75.00 \\
Total & & 28 & $250-1769$ & 21 & 75.00 \\
\hline
\end{tabular}


Table 2. Estimates of genetic variation: number and proportion of polymorphic loci, gene diversity, no. of alleles (Na), effective no. of alleles $(\mathrm{Ne})$, intra- and inter-population similarity indices and gene flow $(\mathrm{Nm})$ within and among the studied $H$. fossilis populations

\begin{tabular}{lccc}
\hline \multicolumn{1}{c}{ Parameters } & & Population & Rupali Hatchery \\
\cline { 2 - 4 } & Jessore & Patuakhali & 23 \\
\hline No. of polymorphic loci & 24 & 24 & 82.14 \\
Percentage of polymorphic loci & 85.71 & 83.71 & $0.271 \pm 0.165$ \\
Gene diversity (Mean \pm SD) & $0.304 \pm 0.183$ & 1.822 \\
Observed no. of alleles (Na) & 1.857 & $0.280 \pm 0.219$ & 1.523 \\
Effective no. of alleles (Ne) & 1.449 & 1.458 & $0.450 \pm 0.251$ \\
Shannon's Information Index (I) & $0.417 \pm 0.224$ & $0.429 \pm 0.303$ & \\
Intra-population similarity index (Si) & & & \\
\hline Inter-population similarity indices & & $80.43 \%$ & $81.17 \%$ \\
Jessore-Patuakhali (\%) & & $82.62 \%$ & 5.755. \\
Jessore -Rupali hatchery (\%) & & & \\
Patuakhali - Rupali hatchery (\%) & & & \\
Overall gene flow (Nm) & & & \\
\hline Note: Na = Observed number of alleles; Ne = Effective number of alleles; $h=$ Nei's (1973) gene diversity; l= Shannon's Information index;
\end{tabular}

Note: $\mathrm{Na}=$ Observed number of alleles; $\mathrm{Ne}=$ Effective number of alleles; $h=$ Nei's (1973) gene diversity; $l=$ Shannon's Information index;

Table 3 Genetic identity (above diagonal) and genetic distance (below diagonal) among three different populations of $H$. fossilis (Nei's 1972, original measure of genetic identity and genetic distance).

\begin{tabular}{lccc}
\hline Population & Jessore & Patuakhali & Rupali hatchery \\
\hline Jessore & $* * * *$ & 0.9330 & 0.9356 \\
Patuakhali & 0.0694 & $* * * *$ & 0.9764 \\
Rupali hatchery & 0.0666 & 0.0238 & $* * * *$ \\
\hline
\end{tabular}

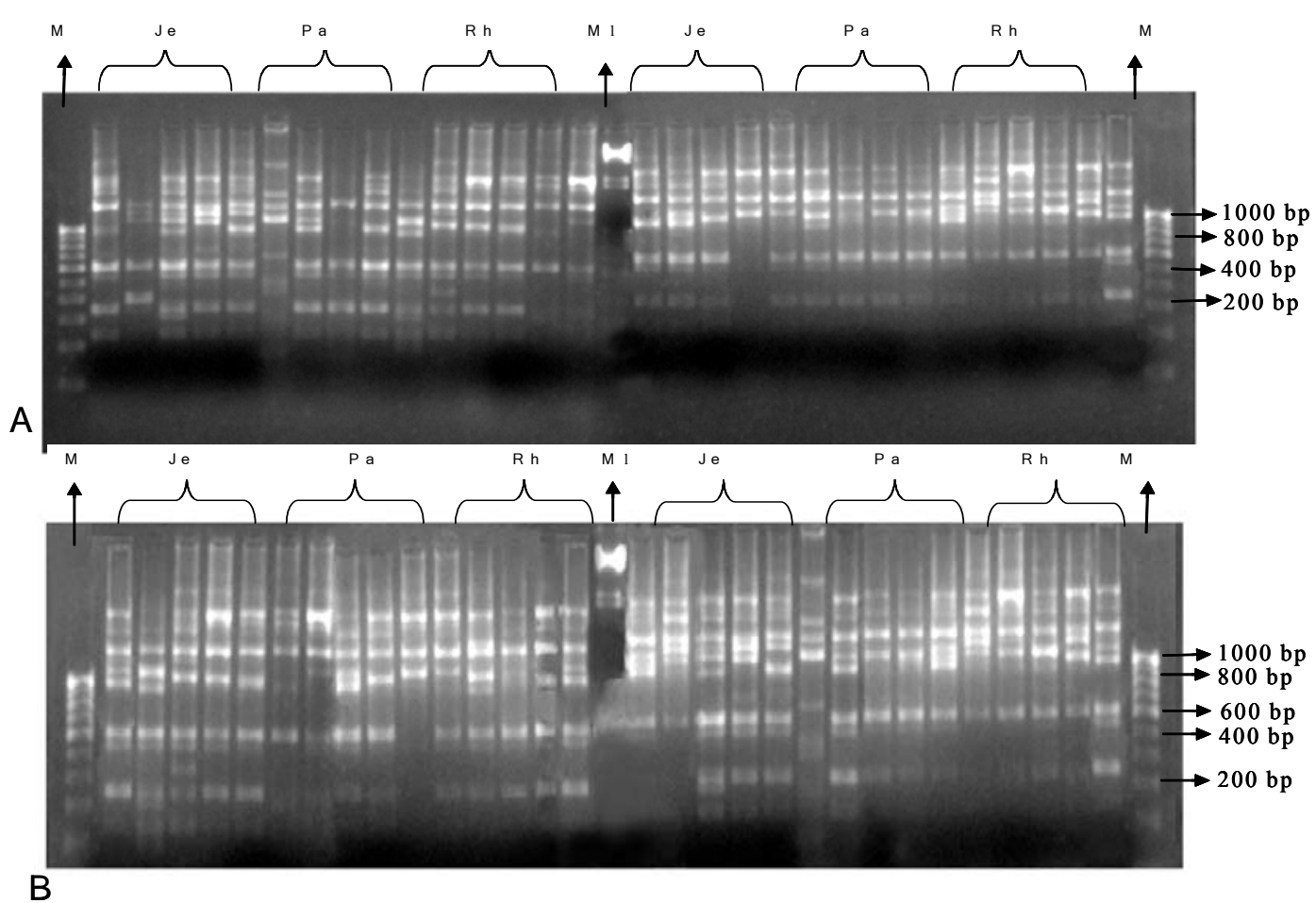

Fig. 1. RAPD profiles of $H$. fossilis for primer OPB01 (A) and for primer OPB02 (B) M: 100bp DNA ladder); M1: Lambda DNA-HindlllEcoRI digest marker; (Je: Jessore, Pa: Patuakhali and Rh: Rupali hatchery). 


\section{Discussion}

Due to simple in operation, the RAPD fingerprinting technique has attracted widespread interests among the researchers. However, genetic characterization with RAPD markers has been constrained by the lack of complete genotypic information due to its dominant nature (Lynch and Milligan 1994). Generally, the number and sizes of the bands generated depend upon the nucleotide sequence of the primers used and the source of the template DNA. The RAPD technique has been found to be suitable for assessing genetic variation in the three populations of $H$. fossilis in the present study.

Populations showing higher frequency of polymorphic loci and lower intra-population band sharing-based similarity index are considered to have higher level of genetic diversity as compared to those showing higher intra-population similarity and lower polymorphic loci. Analysis of four primers detected different levels of genetic diversity in each of the studied populations. A polymorphic locus contains more than one allele and the frequency of the most common allele should be less than 0.95. In RAPD marker analysis, polymorphism is detected as band presence versus band absence and may be caused either by failure to prime a site in some individuals because of nucleotide sequence differences or by insertions or deletions in the fragment between two conserved primer sites (Clark and Lanigan 1993). Using four primers we produced a total of 28 bands in the three populations of which $75 \%$ were polymorphic. The percentage of polymorphic loci in the three different populations of $H$. fossilis was found to be similar to those observed in four different beel and one hatchery population of $H$. fossilis by Sultana et al. (2010) and the African catfish Clarias gariepinus by Saad et al. (2009). In contrast to our findings, Garg et al. (2009) observed a very low level of polymorphism $(18.75 \%)$ at RAPD loci in two Indian populations of $H$. fossilis. The percentage of polymorphic loci obtained in the Jessore population $(85.71 \%)$ is indicative of a relatively higher level of genetic variation. On the other hand, the lowest percentage of polymorphic loci (82.14\%) was found in the Rupali hatchery population.

Liu et al. (1999) reported that RAPD markers were highly reproducible in a size range between 200 and 1500 bp. We found good quality and reproducible PCR products of 250-1769 bp in the $H$. fossilis samples which are similar to those found in the walking catfish Clarias batrachus in India (Garg et al. 2010, Khedkar et al. 2010). The number of alleles per locus is also a measure of gene diversity. A critical assumption for RAPD marker is that there are two alleles per locus (one marker and one null). A higher number of alleles in a population reflect a much better genetic condition over the other populations with lower number of alleles. Similar to proportion of polymorphic loci, the number of alleles is also higher in the Jessore population. We found a mean observed number of alleles across all primers for all loci of $1.857 \pm 0.356$.

The gene diversity was found to be the highest in the Jessore $(0.304 \pm 0.183)$ population followed by the Patuakhali $(0.280 \pm 0.159)$ and the hatchery $(0.271 \pm 0.165)$ population. The estimate of Nei (1972) overall genetic diversity for the entire populations was $(0.309 \pm 0.022)$. Sultana et al. (2010) using RAPD fingerprinting reported gene diversity in five populations of $H$. fossilis ranging from 0.3139 to 0.3703 . Band sharing-based similarity index (SI) is a statistics used to compare the similarity in DNA fingerprints of two samples to make inferences about levels of genetic variation within and between the populations. The similarity index provides a sensitive indicator of relative levels of population homogeneity. Population showing higher intra-population similarity and lower frequency of polymorphic loci are likely to have less genetic diversity as compared to those showing less intra-population similarity. The values for intrapopulation similarity indices $\left(S_{i}\right)$ were slightly higher, ranging from 79 to $85 \%$ than inter-population similarity indices (Sij), ranging from 80 to $83 \%$ and band-sharing based intra-population similarity indices (Si) for Rupali hatchery population $(85.25 \%)$ was higher than those for two other populations. The $S_{i}$ value for Jessore population $(78.75 \%)$ was found to be lowest. This parameter also indicates that the genetic diversity of Jessore population was higher and that of the hatchery population was lower. Almost similar level of intrapopulation similarity indices in all the population implies that individuals within each population were 
genetically close to each other. Sultana et al. (2010) found slightly lower level of intra-population similarity indices in Chalan beel, Pirgonj beel, Rangpur, Mohongonj haor and Narsingdi beel populations of $H$. fossilis (64.95-71.77\%). However our finding is much higher than that reported in stripped dwarf catfish, Mystus vittatus (21.80-28.99) by Tamanna et al. (2012). Khedkar et al. (2010) reported band sharing based similarity indices ranged from 26.00 to $60.00 \%$ in the $C$. batrachus populations.

Gene flow is the transfer of alleles from one population to another and it may lead to a combination of alleles and reducing the genetic diversity between the two gene pools. However, it increases genetic variation within a population as individuals from other populations can bring alleles that could otherwise be absent or rare in the original population. The average gene flow rate $\left(\mathrm{N}_{\mathrm{m}}\right)$ was found to be 5.755 across all primers for all the populations in the present study. The more the gene flow occurs, the more homogeneous the populations will become and the less will be the differentiation.

Genetic identity is the pair-wise measure of populations showing the proportion of individuals which are genetically identical. A higher level of genetic identity (0.9764) found between the Patua khali and Rupali hatchery populations of shing indicates that these two populations are genetically more similar than the others. The genetic identity value obtained in the present study is similar to those in Puntius sarana and $P$. gonionotus (Akter et al. 2010) The genetic identity between two populations is also reflected by the band sharing-based inter-population simila rity. The inter-population or between populations similarity indices $\left(\mathrm{S}_{\mathrm{i}}\right)$ for Patuakhali vs Rupali hatchery populations (82.62\%) was found to be higher than those for all other population pairs. The $S_{i j}$ value for Jessore vs Patuakhali populations (80.43\%) was found to be the lowest. Among the three populations, a higher genetic distance $(0.069)$ was found between the Jessore and Pa tua kha li compared to the Pa tua kha li and Rupali hatchery $(0.023)$ and Jessore and Rupali hatchery $(0.066)$ shing populatins. We did not find any correlation between the genetic distance and geographic distances between the populations.

\section{Conclusion}

H. fossilis is a highly priced, delicious, nutritious and well preferred catfish in Bangladesh. RAPD markers have been found to reveal genetic diversity in shing populations. The result of the present study can be used as baseline information regarding the genetic variation and population structure before undertaking any breeding programme. Study indicated that the genetic variation in the hatchery populations were slightly lower than those of the wild populations. As the culture of the stinging catfish is gaining popularity and expanding rapidly and more and more hatcheries are being engaged in breeding, care should be taken to avoid inbreeding and genetic drift, the two major factors that may ruin the genetic variability and thus biological potential of the important cattish as happened in carp hatcheries in Bangladesh.

\section{Acknowledgement}

This research was supported by Bangladesh Agricultural University Research System through a research project entitled "Study of population genetic structure of the stinging catfish Heteropneustes fossilis (Bloch)", No. 2009/26/AU.

\section{References}

Akter S, Sultana S, Khan MSR, Nahiduzzaman M, Hossain MAR, Alam MS. 2010. Genetic characterization of critically endangered Puntius sarana (Hamilton) and the exotic Barbonymus gonionotus (Bleeker) (Cyprinidae: Cypriniformes) by DNA fingerprinting. Int J BioSci Agric Technol 2(3), 1-27.

Bardakci F, Skibinski DOF. 1994 Application of the RAPD technique in tilapia fish: species and subspecies identification. Heredity 73 , 117-123. http://dx.doi.org/10.1038/hdy.1994.110. PMid:8071079.

Clark AG, Lanigan CMS.1993. Prospects for estimating nucleotide divergence with RAPDs. Mol Biol Evol 10, 1096-1111. PMid:8412651. 
Das BK. 1972. The bionomics of certain air breathing fishes of India together with an account of the development of their air breathing organs. Phil Trans 216, 183-219.

DoF. 2010. Fisheries Statistical Yearbook of Bangladesh (2008-2009), Fisheries Resources Survey System, Fish Fortnight Compendium, Department of Fisheries, Ministry of Fisheries \& Livestock, Government of the Peoples Republic of Bangladesh, pp. 102-103.

Garg RK, Sairkar P, Silawat N, Vijay N, Batav N, Mehrotra NN. 2009. Genetic diversity between two populations of Heteropneustes fossilis (Bloch) using RAPD profile. Int J Zool Res 5, 171-177. http://dx.doi.org/10.3923/ijzr.2009.171.177.

Garg RK, Sairkar P, Silawat N, Batav N, Mehrotra NN. 2010. Assessment of genetic diversity of Clarias batrachus using RAPD) markers in three water bodies of Bhopal. J Environ Biol 31(5), 749-753.

Hadrys H, Balick M, Schierwater B. 1992. Applications of random amplified polymorphic DNA (RAPD) in molecular ecology. Mol Ecol 1:55-63. http://dx.doi.org/10.1111/j.1365-294X.1992.tb00155.x. PMid:1344984

Islam MS, Alam MS. 2004. Randomly amplified polymorphic DNA analysis of four different populations of the Indian major carp, Labeo rohita (Hamilton). J Appl Ichthyol 20(5), 407-412. http://dx.doi.org/10.1111/j.1439-0426.2004.00588.x.

Khedkar GD, Reddy ACS, Persis M, Ravinder K, Muzumdar K. 2010. Clarias batrachus (Linn.1758) population is lacking genetic diversity in India. Mol Biol Rep 37(3), 1355-1362. . http://dx.doi.org/10.1007/s11033-009-9517-3. PMid:19360481

Liu ZJ, Li P, Argue BJ, Dunham RA. 1999. Random amplified polymorphic DNA markers: usefulness for gene mapping and analysis of genetic variation of catfish. Aquaculture 174, 59-68. http://dx.doi.org/10.1016/S0044-8486(99)00007-1.

Lynch M. 1990 .The similarity index and DNA fingerprinting. Mol Biol Ecol 7, 478-494. PMid:2263197.

Lynch M. 1991. Analysis of population genetic structure by DNA fingerprinting. In: DNA fingerprinting approaches and applications (Burke T, Dolf G, Jefferys AJ, Wolf R. eds.) pp 113-126. Basel Institute of Immunology, Basel, Switzerland. http://dx.doi.org/ 10.1007/978-3-0348-7312-3_9

Lynch M, Milligan BG. 1994. Analysis of population genetic structure with RAPD markers. Mol Ecol 3, 91-99. http://dx.doi.org/10.1111/j.1365-294X.1994.tb00109.x PMid:8019690

Nash J HE .1991. "DNA frag, Version 3.03", Institute for Biological Sciences, National Research Council of Canada, Ottawa, Ontario, Canada.

Nei M. 1972. Genetic distance between populations. Am Nat 106, 283-292. . http://dx.doi.org/10.1086/282771.

Nei M. 1973. Analysis of gene diversity in subdivided populations. Proc Natl Acad Sci USA 70, 3321-3323. http://dx.doi.org/10.1073/ pnas.70.12.3321.

Saad YM, Hanafi MS, Essa MA, Guerges AA, Ali SF. 2009. Genetic Signatures of Some Egyptian Clarias gariepinus Populations. Global Vet 3(6), 503-508.

Sultana S, Akter S, Hossain MAR, Alam MS. 2010. DNA fingerprinting of the Asian stinging catfish (Heteropneustes fossilis, Bloch) by Random Amplified Polymorphic DNA markers. Int J Biotechnol Appl 2(2), 05-10.

Talwar PK, Jhingran AG. 1991. Inland Fishes of India and AdjacentCountries. Oxford \& IBH Publishing Co. PVT. Ltd., New Delhi, Vol. 2 : $584 \mathrm{pp}$.

Tamanna FM, Rashid J, Alam MS. 2012. High levels of genetic variation revealed in wild and hatchery populations of the stripped dwarf catfish Mystus vittatus (Bloch) (Bagridae: Siluriformes) in Bangladesh by Random Amplified Polymorphic DNA techniques. Int $J$ Adv Biol Res 2(2), 322-327.

Welsh J, McClelland M. 1990. Fingerprinting genomes using PCR with arbitrary primers. Nucleic Acids Res, 18, 7213-7218. http://dx. doi.org/10.1093/nar/18.24.7213 PMid:2259619 PMCid:332855

Williams JGK, Kubelik AR, Livak KJ, Rafalski JA, Tingey, SV. 1990. DNA polymorphisms amplified by arbitrary primers are useful as genetic markers. Nucleic Acids Res 18, 6531-6535. http://dx.doi.org/10.1093/nar/18.22.6531 PMid:1979162 PMCid:332606

Yeh FC, Yang RC, Boyle T. 1999. POPGENE version 1.31: Microsoft Window-based freeware for population genetic analysis. ftp://ftp. microsoft.com/Softlib/HPGI.EXE. 